\title{
STRATEGI DAKWAH MOHAMMAD NATSIR: RESPON TERHADAP KRISTENISASI DAN NATIVISASI DI INDONESIA
}

\author{
Oleh: \\ Nofa Nur Rahmah* \\ Dosen Sekolah Tinggi Ilmu Qur'an Ar-Rahman Jonggol, Jawa Barat \\ nofanurrs@gmail.com
}

\begin{abstract}
The evangelism and nativisation which is one of lack of aqidah which until today remains a da'wah challenge. Muhammad Natsir as one of the leading national and international has da'wah strategy to oversee the Muslim faith. This research focuses on the study of how the Mohammad Natsir's da'wah strategy in response evangelism and nativisation. This is a qualitative research with a historical approach analysis, and using techniques of data collection is the library research and interviews with DDII competent administrators as a primary source. As for other sources used are books, journals that discussed the history of evangelism and nativisation in Indonesia. The analysis method used in this study is an inductive. The type of this research is explanatory. The results of this study, concluded that M. Natsir's da'wah strategy in response to evangelism and nativisation is to strengthen the Islamic faith in a way to make people aware their existence as a Muslim and aware their missionary challenge through education, da'wah fardhiyah, structural da'wah,and cultural da'wah. The steps are chosen is to educate every Muslim and to unite ummah in the middle of Indonesian diversity.
\end{abstract}

Keywords: Da'wah, Strategy, Evangelism, Nativisation.

\section{A. PENDAHULUAN \\ Ketegangan dengan muatan keagamaan (antara Islam dan Kristen) sejak awal perjumpaannya membuahkan peristiwa-peristiwa}

kerusuhan seperti beberapa yang terjadi pada perang Jawa (1925-1930) masa Hindia Belanda hingga masa reformasi. Gerakan Kristenisasi dalam rangka mencapai misi 


\begin{abstract}
"Transformasi Indonesia"1 di masyarakat masih menjadi ancaman bagi aqidah umat Islam Indonesia. Strategi Kristenisasi tersebut merasuki berbagai aspek, guna menguasai bidang politik dan ekonomi. (Khalidy 1953, 23)
\end{abstract}

Hasil Kristenisasi di Indonesia dijabarkan pula dalam pernyataan Frank Snow ${ }^{2}$ dengan kalimat "cukup mempesona" untuk mengungkapkan capaian keberhasilannya dalam melakukan missi $^{3}$ di Indonesia. Laporan dari Dr. Ebbie Smith kepadanya menyatakan bahwa Republik Indonesia mengalami pertumbuhan gereja yang lebih hebat dari pada daerah lain ${ }^{4}$. Terlebih pada

1 Transformasi merupakan tujuan dari kristenisasi dengan indikator semua manusia mengetahui tentang ajaran Kristen dan masuk ke dalamnya menjadi satu. Lihat Kesatuan Tubuh Kristus Menuju Transformasi Bangsa oleh Pdt. Niko Njotorahardjo. Dalam : Niko Njotorahardjo. Dkk, Transformasi Indonesia : Pemikiran dan Proses Perubahan Yang Dikaitkan dengan Kesatuan Tubuh Kristus, (Jakarta : Metanoia, 2003), hlm. 1.

2 Adalah seorang tamatan Universitas London dan London Bible College yang telah melayani dengan Overseas Missionary Fellowship (OMF) di Timur tahun 1958-1970. Ia pun melayani terutama dalam pendidikan Kristen di Indonesia yakni daerah Jawa Tengah dan Sulawesi.

Istilah misi digunakan pada Katolik sedangkan penginjilan ( evangeliz ) sebutan bagi Kristen.

4 Jumlah perkembangan jamaat gereja yang dilaporkan pada gereja Batak di Sumatra Utara dalam tiga gereja yang terpisah yakni 819.000, 85.000, dan 65.000. sedangkan di Pulau Nias telah melahirkan sebuah gereja dengan 225.000 anggota. Diungkapkan pula bahwa sejak pergolakan pada tahun 1965, ketika PKI yang berusaha merebut kekuasaan digagalkan, Gereja Batak Karomeningkat jumlah anggotanya daerah Jawa Tengah dan Jawa Timur yang mengalami pertumbuhan gereja (sangat besar).

Indonesia melaporkan sejak tahun 1980-an setiap tahunnya laju pertumbuhan umat Katholik sebesar 4,6\%, Protestan 4,5\%. Selain itu pula dinyatakan dalam buku Gereja dan Reformasi oleh Pendeta Yewanggoe (th.1999) bahwa jumlah umat Kristiani di Indonesia berjumlah 20\%. Sedangkan menurut data Global Evangelization Movement telah mencatat pertumbuhan umat Kristen di Indonesia mencapai lebih dari 40.000 .000 orang (19\% dari total jumlah penduduk Indonesia). Sedangkan data BPS (Badan Pusat Statistik) melaporkan penurunan jumlah umat Islam di Indonesia dalam kurun waktu sepuluh tahun terjadi seperti di daerah Jawa Tengah, NTT dan wilayah Indonesia lainnya. Sehingga tahun 2010 menjadi $85,1 \%^{5}$ dari sebelumnya pada tahun 2000 sebesar 87,55\% Angka tersebut membuktikan kekhawatiran terhadap ancaman aqidah menjadi beralasan kuat. (Data BPS th 2000)

Tantangan lain terhadap aqidah umat Islam selain dari fakta Kristenisasi adalah nativisasi. Nativisasi merupakan masalah bagi

menjadi dua kali lipat dalam dua tahun. Mencapai 65.000 jiwa pada tahun 1967. Ribuan orang dibaptis di Jawa Tengah dan Jawa Timur selama periode yang sama. Gereja Southern Baptist di Jawa dan Sumatra mengalami kenaikan jumlah anggota tiga kali lipat pada tahun 1969.

${ }^{5}$ Islam : 207.176.162 ; Kristen : 16.528.513 ; Katolik : 6.907.873 ; Hindu : 4.012.116 ; Budha : 1.703.254; Khong $\mathrm{Hu} \mathrm{Chu} \mathrm{:}$ 117.091. sumber http://sp2010.bps.go.id/index.php/site/tabel ?tid=321 
muslim Indonesia yang meletakkan titik tekannya kepada pengenalan identitas bangsa. Proses nativisasi ini sudah sejak lama digunakan oleh Belanda ketika menjajah Indonesia dengan tujuan menjauhkan Islam dari masyarakat Nusantara. Hal ini disebabkan Islam menjadi musuh terberat dalam melancarkan misi penjajahan. (Abdullah 1988, 114) Menghidupkan candi-candi dengan mengagungkannya sebagai peninggalan peradaban awal Nusantara adalah salah satu bentuk menyamarkan peranan Islam dalam pembentukan bangsa ini.

salah $\begin{array}{rrr}\text { Politik } & \text { Nativisasi } & \text { menjadi } \\ \text { satu } & \text { ancaman } & \text { Islam }\end{array}$ dikarenakan membentuk penilaian terhadap Islam bahwa Islam diposisikan sebagai agama asing yang merebut kebudayaan asli yakni Hindu Budha yang telah ada sebelumnya. Usaha sistematis politik itu bertujuan untuk memarginalkan peran kesejarahan Islam dengan cara menyanjung budaya-budaya setempat non-Islam.

Nativisasi pada posisi sebagai tantangan internal akan menjadi pertimbangan dalam melakukan implementasi dakwah kultural di masyarakat, yang sering dikenal dengan takhayul, bid'ah, khurafät. Sehingga kiranya perlu ada langkah tersendiri dalam meresponnya dan menentukan strategi dakwah agar Islam tetap pada kemurniannya dan menjadi rahmatalil alamiin.

Menguraikan dan mempelajari sejarah merupakan salah satu cara dalam mengatasi sebuah permasalahan. Oleh karena itu, penelitian ini mengkerucutkan pada bagaimana konsep dan strategi Kristenisasi dan nativisasi serta langkah dakwah Muhammad Natsir dalam merespon kedua tantangan tersebut dalam beberapa masa periode.

\section{B. METODE PENELITIAN}

Penelitian ini bersifat kualitatif $^{6}$ yang menghasilkan data deskriptif $^{7}$. Penelitian ini menjadikan realitas sosial sebagai sesuatu yang holistik/utuh, kompleks, dinamis, penuh makna, dan bersifat interaktif (reciprocal) dengan objek yang alamiah (berkembang apa adanya, tidak dimanipulasi oleh peneliti dan kehadiran peneliti tidak mempengaruhi dinamika pada objek tersebut) sehingga metode ini dapat disebut dengan metode post positivisme. (Kaelan 2012, 13)

Tekhnik pengumpulan data yang digunakan adalah dengan telaah pustaka dan dokumen tertulis baik yang bersifat primer maupun sekunder. Selain itu dilakukan wawancara dengan orang-orang yang terlibat dan atau memahami dakwah M. Natsir, seperti pengurus Dewan Dakwah Islam Indonesia (DDII), dan juga kepada tokoh yang dianggap menunjang dalam menentukan analisis penelitian. Penelusuran dilacak di pusat-pusat data seperti perpustakaan, DDII, serta lapangan yang menunjukkan fakta nyata data atau permasalahan yang masih dapat terjangkau.

\footnotetext{
6 Hasil data dan analisisnya bersifat kualitatif. : Sugiyono, Metode Penelitian Kombinasi, (Bandung : Alfabeta, 2013), hlm. 13.

${ }^{7}$ Data-data verbal yaitu suatu uraian tentang pemikiran dalam hubungan keagamaan.
} 
Pendekatan yang digunakan dalam penelitian ini menggunakan historis dan analisis. Selain itu juga menggunakan metode rekonstruksi biografis. Dengan analisis data secara induktif. Tipe penelitian termasuk ke dalam eksplanatori, yakni mencari hal yang baru dari fakta sejarah berupa aplikasi pemikiran dakwah $\mathrm{M}$. Natsir untuk kemudian dirumuskan secara analisis sebagai sebuah pola strategi dalam merespon tantangan Kristenisasi dan nativisasi. Sehingga validitas data dilakukan dengan cara credibility.

\section{KONSEP DAN STRATEGI KRISTENISASI DAN NATIVISASI}

\section{Konsep Dan Strategi Kristenisasi}

Istilah Kristenisasi - dalam agama Kristen dikenal dengan gerakan misi atau penginjilan mengandung arti misi yang dilakukan dalam bentuk yang sistematis, terorganisasi dan terencana untuk megkristenkan umat diluar Kristen. (Bakhtiar 2005) Kristenisasi juga sering disebut dengan penginjilan.

Secara etimologis, kata
penginjilan adalah berasal dari
bahasa Yunani, euangelion yang
artinya "kabar baik". Kata benda
euangelistes berarti "penginjil".
Sedangkan kata kerja euangelizesthai
yakni "menyampaikan kabar baik
Penginjilan adalah membagikan atau
memproklamasikan berita atau
menyebarkan injil bahwa Yesus
Kristus telah mati bagi dosa-dosa kita
dan dibangkitkan dari kematian
sesuai Al-kitab, dan sebagai Tuhan
yang memerintah, Dia sekarang

menawarkan pengampunan dosa dan anugrah yang membebaskan dalam Roh Kudus bagi semua orang yang bertobat dan percaya." $"$.(Rintis 2012,8) Pengertian Kristenisasi memiliki makna yang sama dengan zending, misi, pekabaran injil. (Anshory 2013, 15)

Karya misi juga diartikan sebagai perintisan berdirinya gereja di daerah yang belum mengenal Kristen. Misionaris adalah orang yang diutus mewartakan injil atau kabar baik kepada orang yang belum mengenal Kristus. (Maryanto 2004, 138-139) Seorang Kristen akan bersalah jika tidak berperan sebagai penginjil, dan tidak seorangpun dibenarkan untuk melarikan diri dari tugas penginjil dengan alasan apapun. Sesungguhnya penginjilan harus menjadi gaya hidup bagi setiap orang Kristen. (Purwantara 2012, 23)

Beberapa strategi yang digunakan dalam melancarkan tujuan misi Kristenisasi dapat dirangkum dalam bagan berikut :

\footnotetext{
8 Pernyataan ini merupakan hasil Kongres tentang penginjilan dunia (world evangelization) pada tahun 1974 di Lausanne. Penginjilan yang efektif adalah dapat menkonversikan orang dari kepercayaan lain atau orang yang tidak percaya menjadikan percaya kepada Yesus Kristus.
} 


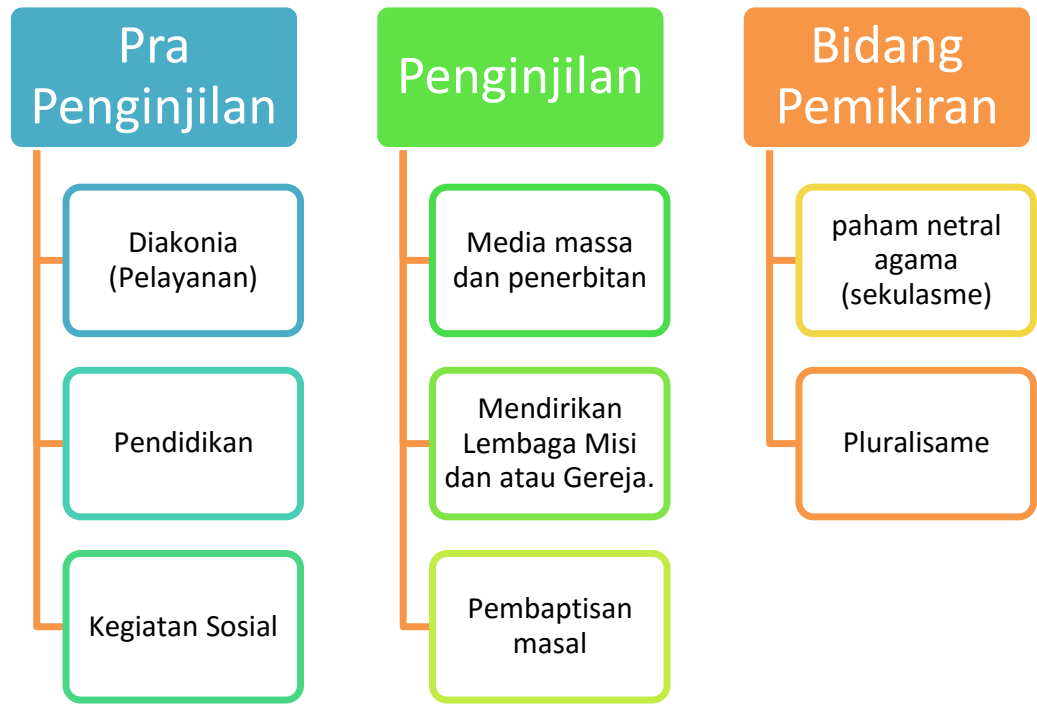

\section{Konsep Dan Strategi Nativisasi}

Berdasarkan pegertiannya, Nativisasi juga dapat disebut dengan pribumisasi. Artinya, Menjadikan unsur-unsur alami (asal) sebagai objek yang harus dihindari dari pengaruh gejala asing. Dalam gagasan "Pribumisasi ilmu Sosial" yang dalam penelitiannya menggunakan metode (juga merupakan hasil sebuah gagasan) "grounded research" yang menghasilkan sebuah teori dengan terlebih dahulu mengkonstruksikan suatu teori yang akan dipakai sebagai kacamata untuk melihat objek. Sehingga realitas dibentuk oleh teori. (Kuntowijoyo 1994, 14)

Definisi Muhammad Natsir mengenai Nativisme atau kebatinan (dalam wawancara disebutkan demikian) ialah faham yang menjadikan manusia cenderung untuk percaya pada kepercayaan nenek moyang, pada "alam". sifat nativisme sendiri dibedakan menjadi dua macam, yaitu "alamiah" dan ada yang “terorganisir". (Pratiknya, 1989, 102)

M.Natsir menyebut nativisasi sebagai proses penyejarahan yang mewancanakan Islam tidak memiliki peran berarti bagi perkembangan peradaban. ( Aziz, Islamia vol V No 2 th 2009, 73) Nativasi dalam kaitannya terhadap kebudayaan, didefinisikan sebagai usaha yang sistematis maupun tidak yang dijalankan untuk menghilangkan peran kesejarahan Islam dan umatnya dari suatu negri dengan cara mengangkat budaya lokal setempat. (Susiyanto 2010, 90)Budaya tesebut pun diangkat melalui proses rancang ulang yang tidak jarang adalah hasil rekayasa untuk memarginalkan Islam. Proses nativisasi di negri Islam yang hampir mirip dengan "publikasi" kebudayaan candi adalah terjadinya proses identifikasi Mesir dengan peradaban Piramida.(Susiyanto, Islamia Vol.II No.2, 82-92)

Proses nativisasi merupakan salah satu strategi yang digunakan untuk memecahkan persatuan Nusantara oleh kolonialisme agar dapat mudah dikuasai. Pemutarbalikan sejarah yang menjadikan Islam (diwakili dengan kerajaan Demak) sebagai agama yang meruntuhkan Hindu (diwakili dengan kerajaan Majapahit) merupakan hal yang disengaja oleh Snouck Hourgronye yang memiliki strategi 
menanamkan rasa "Kebangsaan" untuk melemahkan keteguhan islam dari seorang muslim di Indonesia. (Hamka 1982, 12) Penjabaran bentuk

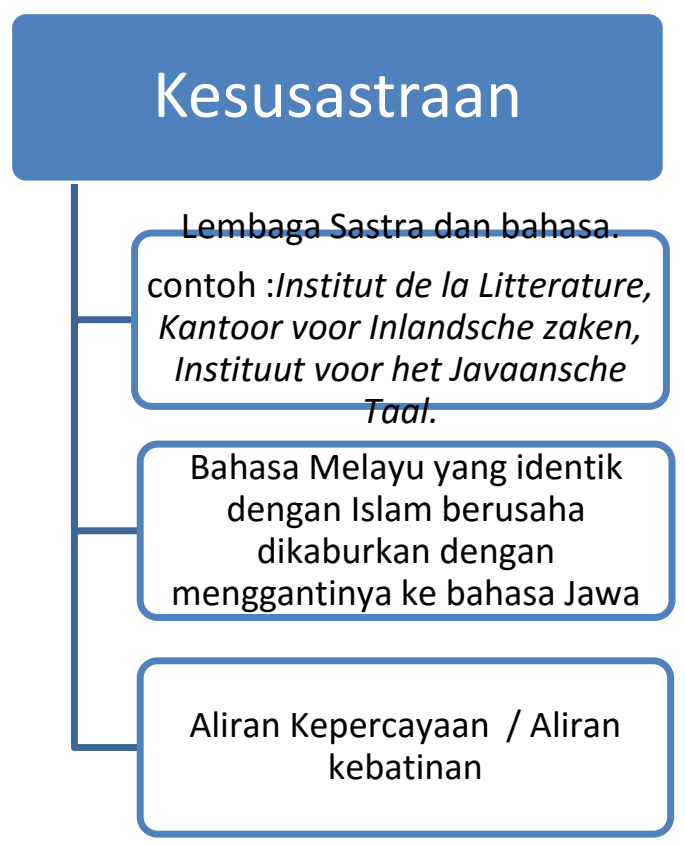

\section{STRATEGI DAKWAH M. NATSIR IMPLEMENTASINYA}

\section{Biografi Muhammad Natsir}

Mohammad Natsir (M. Natsir) lahir pada tanggal 17 Juli 1908 dari pasangan Idris Sutan Saripado dan Khadijah di Kampung Jembatan Berukir, Kota Alahan Panjang. Sejak kecil sudah aktif mengaji dan berdialog hingga pernah tinggal di rumah Haji Musa. (Basri 2008, 5)

Natsir menempuh pendidikan dasarnya di sekolah Belanda dan mempelajari agama dari para alim ulama, pada usianya yang kedelapan belas ia masuk sekolah partikiler HIS Adabiyah di Padang. (Luth 1999, 22) Ia mulai belajar bahasa Arab dan fiqh di Madrasah Diniyah pada sore hari strategi nativisasi dalam penelitian ini di batasi dalam dua aspek, yakni : kesusastraan dan sejarah.

\section{Sejarah}

Menciptakan dongeng dongeng sebagai pengganti ajaran Islam

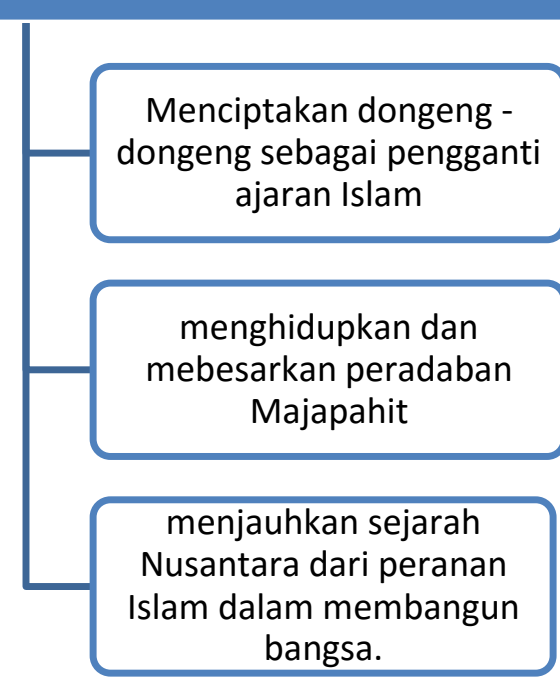

dan malamnya mengaji al-Qur'an, kemudian pagi harinya belajar di HIS (1916 hingga 1923).

M. Natsir aktif mengikuti kegiatan ekstrakulikuler yakni JIB (Jong Islamieten Bond) ketika ia masuk MULO (Middlebare Uitgebreid Larger Onderwys) di Padang (1923). ${ }^{9}$ Kemudian bulan Juli 1927 beliau meneruskan pendidikannya ke Bandung di AMS (Algemeene Middelbare School) ${ }^{10}$.

\footnotetext{
${ }^{9}$ Natsir ikut dalam pandu Natipiji (Nationale Islamitische Padvindrij) yakni kepanduan Nasional Indonesia yang memiliki wawasan kebangsaan. Agus Basri. Politik Melalui Jalur Dakwah. (Jakarta : Media Dakwah, 2008), hlm. 7 ; ketika di MULO ini pemahaman Natsir tentang sistim kolonial jauh lebih baik dari pada ketika ia sekolah di HIS.

10 Di AMS ia mulai menekuni ilmu pengetahuan Barat lebih dalam. Ia
} 
(Suhelmi 2012, 26-27) Diakui olehnya, di Bandung inilah pikirannya berubah tentang citacitanya yang ingin menjadi Meester (sekarang disebut Sarjana Hukum). (Basri 2008, 8). Ia lebih tertarik pada perjuangan Islam. (Muridan dalam Komunika vol.3 No.1 2009, 63-74) M. Natsir yang kala itu bersama A. Hasan mengelola majalah "Pembela Islam". Selain itu, M. Natsir juga sempat menjadi ketua JIB Bandung tahun 1928-1932.

Pendidikan di AMS memberikan M. Natsir kesempatan untuk bergaul dan mempelajari peradaban Barat. Tahun 1931-1932 Natsir mengikuti kursus guru diploma Langer Onderwijs (LO). Selanjutnya ia mulai mengajar di MULO. Selama sepuluh tahun 1932-1942 beliau menjabat sebagai Direktur Pendidikan Islam di Bandung. Tahun 1938, M. Natsir mulai terlibat dalam politik, selanjutnya pada 3 Januari 1946, Natsir dipilih menjadi Mentri Penerangan dalam Kabinet RI pertama. Setelah itu beliau diangkat menjadi ketua umum Partai Masyumi hingga 1958. (Mohammad Natsir 1980). Tahun 1950 hingga 1951 menjadi Perdana Mentri Republik Indonesia, Anggota Parlemen RI, Anggota Konstitusi RI. Tahun 1956 M. Natsir memimpin sidang Muktamar Alam Islamy di Damaskus. Ia juga menjabat sebagai wakil Presiden Kongres Islam Sedunia yang berpusat di Pakistan.

mempelajari berbagai aspek sejarah peradaban Islam, Romawi, Yunani, dan Eropa, melalui buku-buku berbahasa Arab, Prancis dan Latin. Pada usia 21 tahun ia telah menguasai lima bahasa (Belanda, Aab, Ingris, Perancis, Latin).
Keterlibatannya dalam PRRI membuatnya dikirim ke Batu Jawa Timur tahun 1960-1962 (karantina). Selama menjadi tahanan Natsir juga tetap berdakwah, selanjutnya Natsir pada masa orde baru (1962-1966) pun ditahan di Jalan Keagungan 62 Jakarta. Partai Masyumi akhirnya dibubarkan pada tanggal 17 Agustus 1960, sedangkan M. Natsir dibebaskan Juli 1966. Kemudian ia mendirikan Dewan Dakwah Islam Indonesia (DDII) tahun 1967. Beliau menjabat sebagai ketua hingga akhir hayatnya.

Natsir juga menjadi anggota Muslim World League (Rabithah Alam Islamy) Mekkah sejak 1969. Pada 1976 ia menjadi anggota Majlis A'la Al-Alamy lil Masajid (Dewan Masjid sedunia) di Mekkah. Muhammad Natsir wafat pada tanggal 6 Februari 1993 di Rumah Sakit Cipto Mangunkusumo (RSCM) Jakarta pada usia beliau 85 tahun. Pada masa kritis nya (ketika diruang ICU) M. Natsir masih menjadi target dalam kristenisasi. Upaya Kristenisasi tersebut pun gagal.

\section{Strategi Dakwah M. Natsir Merespon Kristenisasi Dan Nativisasi}

Bagaimana strategi dakwah M.Natsir merespon Kristenisasi dan Nativisasi terangkum dalam tabel berikut: 


\begin{tabular}{ll}
\hline Ideologi & $\begin{array}{l}\text { Tauhid (benteng yang paling kokoh agar tidak mudah } \\
\text { dilemahkan lawan dan menjadi mangsa) }\end{array}$ \\
\hline Visi & terciptanya negara sejahtera yang penuh ampunan Allah \\
& (Baldatun thoyyibatun wa rabbun ghafur). \\
Konsep & amar ma'ruf nahi munkar dan beretika \\
Metode & Hikmah dan mawwadah fil qurba melalui dakwah bil hal, \\
& dakwah bil lisan, dakwah bil qalam. (terangkum dalam \\
& gambar) \\
Cara & Memperkuat tauhid setiap muslim, Mencerdaskan dan \\
& menyadarkan muslim terhadap masalah untuk dapat \\
& mengambil peran dalam dakwah, menciptakan kerukunan \\
& umat (toleransi)
\end{tabular}

Setiap strategi yang digunakan oleh M. Natsir, inti dari setiap bentuk langkanya bertolak pada "Tauhid". Dengan ketauhidan, dan membuka "tabir" masalah yang ada, M. Natsir menata metode dan mengambil peluang kesempatan yang ia miliki untuk berdakwah guna mencapai tujuan yakni terjadinya transformasi sosial. Transformasi sosial ini digambarkan oleh M. Natsir menjadi "Baldatun Thoyyibatun wa Robbun Ghafur". Tauhid tersebut dilengkapi dengan ilmu, sehingga akan menumbuhkan daya tahan (imunitas) yang kuat dalam diri serta kepercayaan menghadapi berbagai tantangan baik Kristenisasi ataupun nativisasi dan lainnya, disamping itu melahirkan hikmah yang dapat mengontrol diri dalam bersikap agar meletakkan sesuatu pada tempatnya, selain dengan hikmah diperlukan mawwadah fil qurba (jembatan rasa) yang menjadi latar berlakang berbuat dengan mengunakan kasih sayang yang dilahirkan dari jiwa dan bukan sekedar tampak dalam lahirnya saja. Dapat disimpulkan, antara konsep pemikiran dan strategi dakwah M.Natsir dapat dikatakan "taat azas". Tauhid sebagai landasan dasar di aplikasikan dengan mengawal aqidah umat dari berbagai ancaman.

\section{E. ANALISIS STRATEGI DAKWAH M. NATSIR}

\section{Analisis gerak}

Berbagai bentuk aksi Kristenisasi dan nativisasi yang terkonsep dengan baik dan tersistimatis menjadi sebab reaksi dari dakwah M. Natsir untuk mengatasinya. Adapun reaksinya melalui ceramah, karya tulis, memasuki dunia politik (pemerintahan) dan merangkul umat untuk berdakwah jama'i. Hal ini dikelompokkan menjadi tiga analisis katagori gerakan yakni dakwah fardhiyah, dakwah syiasi dan dakwah jama $i$. Ketiga gerak langkah tersebut bermuara pada hakikat geraknya yakni penguatan aqidah, 
meningkatkan ilmu dan wawasan kaum muslimin, meningkatkan kepercayaan diri dan mempererat persatuan.

\section{Dakwah}

fardhiyah

melandaskan setiap materinya kepada tauhid. Ideologi tersebut dinilai akan mampu menciptakan ketahanan yang kokoh dalam menghadapi berbagai rintangan dakwah sebagai pejuang agama. Sebagaimana tujuan hidup yang dijelaskan M. Natsir dalam bukunya Fiqh dakwah yakni keridhaan Ilahy yang memungkinkan tercapainya hidup sebenar-benarnya hidup sesuai dengan Qs. Al-ankabut 64 , memiliki mutu yang lebih tinggi mutunya dari hidup duniawi, jiwajiwa tauhid inilah yang diakui menjadi sallah satu sebab lahirnya sikap patriotisme dan cinta tanah air dengan semangat jihad fii sabilillah. Sebagaimana sejarah mencatat bahwa kemerdekaan Indonesia merupakan hasil dari gerakan ulama dan santri. ${ }^{11}$ (Puar 1991, 114) Natsir memilih menanamkan penekanan ibadah kepada shalat dan puasa sebagai refleksi dari pembelajaran tauhid sebagaimana yang ia sadari ketika membaca masa kecilnya.

Tauhid menjadi tempat bertolak (sebutan dari M. Natsir sebagai landasan dasar) memiliki alasan yang kuat. Ini dapat lebih

11 Rangkaian dari semangat jihad fii sabilillah itu ialah semangat berani mati dan semangat membela tanah air sebab cinta tanah air (Hubbul Wathan minal iIman) adalah sebagian dari iman yang merupakan cikal bakal dari patriotisme bangsa Indonesia. Dr. Douwes Dekker (Setyabudi) pernah menyatakan, bahwa kalau tidak ada semangat Islam sudah lama kebangsaan yng sebenarnya lenyap dari Indonesia. dikuatkan argumentasinya dengan penuturan Syeid Naquib al-Atas bahwa sesungguhnya masyarakat Islam yang benar (mematuhi ajarannya) dalam menghadapi perubahan dan pembangunan serta perkembangan dan kemajuan tidak akan terjadi kebingungan identitas akibat adanya jurang antar generasi, atau al-Attas menyebutnya dengan penyakit generation gap dan identity crisis. Hal ini dikarenakan hakikat Islam tidak berubah yakni memiliki satu tujuan hidup yang sudah jelas dan berlaku untuk semua golongan usia dan untuk segala masa. (Al Attas 2001, 92-94)

Kesadaran politik bahwa kolonialisme menciptakan diskriminasi status dan posisi Islam dibandingkan dengan posisi dan status Kristen baik dari berbagai bentuk aksi sebagaimana pemparan dalam data, membuat Islam semakin merasa minoritas dalam segi kualitas, hal ini membuat ikatan ideologi Persatuan Islam antar anggotanya semakin kuat. Karena itu, pengasahan sensitifitas M. Natsir dalam membaca hubungan Islam Kristen di masa selanjutnya dilakukan secara lebih analisis. Hasil analisis ini yang kemudian menjadi alasan ia mengatur cara dan langkah untuk membendung aksi tersebut dengan menguatkan imunitas kaum musliminnya melalui penanaman tauhid disamping aksi eksternal lainnya.

Nativisasi yang terorganisir jika dikaji lebih dalam akan ada keterkaitan dengan golongan Kristen maupun golongan sekularisasi sendiri. Karenanya, M. Natsir mengungkapkan, untuk menghadapi nativisme yang "alamiah" diperlukan 
pengembangan dakwah yang benarbenar dapat menyantuni kebutuhan spiritual umat secara Islami. Seperti contohnya adalah dengan menterjemahkan uraian kandungan al-Qur'an dengan lagu-lagu Jawa yang dilakukan oleh kiai ulama sebagai wujud konkrit dakwah budaya setempat.

Hal ini sebagaimana yang diterangkan pula dalam fiqh dakwah Natsir, bahwa dakwah perlu disampaikan dengan bahasa yang disesuaikan dengan objeknya. Tentu saja, tanpa mengubah dan tidak menyimpang dari ajaran Islam yang murni. Sedangkan untuk Nativisasi yang "terorganisir" atau "disengaja" disampaikan dalam wawancara percakapan antar generasi, lebih ditekankan oleh Natsir untuk dirumuskan pendekatan dan perencanaan yang tepat dalam berdakwah. Untuk mencapai ini, M. Natsir pun melalui jalur dakwah syiasi dan dakwah Jama'i. Adanya tujuan/ visi dan misi bersama menjadikan alasan kuat untuk beberapa orang melakukan kerjasama.

Peningkatan wawasan keislaman dan sejarah kebudayaan Islam yang menjadi pilihan pesan dakwah M. Natsir salah satunya adalah untuk mengembalikan kepercayaan diri seorang Muslim. Hal ini dilakukan untuk menghilangkan jiwa kerdil dalam setiap muslim melawan penjajahan (merasa bahwa penjajahan adalah takdir Tuhan yag harus diterima) serta nativisasi.

\section{Analisis Aksi}

Mosi Integral serta gerakan lainnya yang dilakukan oleh $\mathrm{M}$. Natsir menitik beratkan pula pada persatuan, baik terhadap kaum Nasionalis-sekuler maupun umat selain Islam. Ia mengajak kepada seluruh elemen masyarakat untuk menghadapi musuh bersama yaitu penjajah. Tidak hanya itu, ketika Indonesia dinyatakan merdeka ia pun tetap merangkul dan mengesampingkan perbedaan guna mencapai tujuan baldatun thoyibatun wa robbun ghofur.

Terhadap kerusuhan yang terjadi antara umat Islam dan Kristen Natsir (bersama rekan lainnya) mencoba mengambil langkah mendamaikan baik melalui pendekatan personal (kepada pihak penasehat umat Kristiani) hingga tertuang dalam rancangan kebijakan dalam pemerintahan. Namun, ia cukup tegas dan kritis dalam setiap langkahnya. Hal ini terefleksikan pada implementasi dakwahnya. Analisis aksi M. Natsir tercermin dalam konsep sebagai berikut :

\section{a) Strategi Dakwah bil Hal}

Dakwah bil hal, dilakukan oleh M. Natsir dengan tetap memegang prinsip yakni menggunakan cara "hikmah" dan "mawadah fil qurba" penempatan cara hikmah yang dimaknai dengan sikap bijaksana, dilakukan oleh $\mathrm{M}$. Natsir dengan keberanian dan tegas. Dakwah bil hal yang dilakukan oleh Natsir antara lain adalah "Mosi Integral" dalam rangka menyatukan NKRI pada masa pasca proklamasi kemerdekaan. 
Sementara itu, dalam ketatanegaraan, peran M. Natsir yang menduduki jabatan-jabatan strategis menjadi salah sau peluang M.Natsir dalam berdakwah seperti, membentengi umat terhadap kristenisasi melalui kebijakan negara, Modus Vivendi, Konstituante, PRRI, mosi integral, dan petisi 50 .

Tidak hanya dalam lingkup Nasional, M. Natsir pun menjalin hubungan kerjasama dengan dunia luar. Ukhuwah Islamiyah mampu menghapuskan batas-batas geografis dari berbagai belahan dunia.

Langkah lain M. Natsir menempuh jalur pendidikan, beberapa kebijakan baik yang diberlakukan oleh Pemeritah Hindia Belanda maupun sekolah misi (contohnya: penggunaan bahasa yang menggunakan bahasa asing $^{12}$ (Banawiratma, 34), Ordonasi guru, Penertiban sekolah liar, dan sebagainya) digambarkan oleh Alwi Shihab merupakan sebuah bentuk "kristenisasi yang dipaksakan". 13 (Alwi 1998, 89) Bidang pendidikan juga merupakan sarana efektif dalam

12 Bahasa asing yang waktu itu dimaksud adalah Bahasa Belanda yang merupakan faktor penting dalam sebuah pendidikan, dalam pendidikan yang dibangun oleh van lith, kemampuan berbahasa Belanda merupakan kunci untuk memasuki perubahan sosial. Dengan kemampuan itu orang Jawa akan dapat semakin mengerti perkembangan Barat dan menjadi bagian dari mereka.

13 Subsidi kepada sekolah misi. Pada masa sebelum merdeka, kebijakan kolonialisme dalam bidang pendidikan merupakan bentuk usaha "Kristenisasi yang dipaksakan" terhadap pribumi dengan diserahkan pemanfaatan fasilitas dan pengelolaan bidang ini kepada sekolahsekolah misi. membentuk pemikiran yang diarahkan sebagai penunjang tujuan pendidikan tersebut. Melalui kurikulum pendidikan, dan metode pengajaran, serta kebijakan lainnya sebagai sarana pencapaian tujuan. Pendidikan dapat dikatakan merupakan sebuah alat pengantar para generasi ke arah yang dikehendaki.

Natsir memiliki pandangan, sikap kritisnya dan mampu melihat penyimpangan agama dalam masyarakat saat ini, dikarenakan ia sejak kecil selalu ditanamkan pentingnya mendirikan shalat dan melaksanakan puasa. Dan wawasan lainnya, ia dapati dari pengajian yang diikutinya di madrasah diniyah selepas sore hari. Artinya, dengan penerapan shalat dan puasa serta wawasan yang menunjang dapat mempengaruhi keteguhan aqidah Islamiyah dan mampu membentuk karakter seorang muslim yang memiliki kepribadian, dan berhikmah tidak melepaskan shibgoh.

Keteguhan aqidah, dan wawasan yang luas akan Islam, mampu melahirkan sikap kritis dan berani menegakkan sebuah hal yang diyakini kebenaran. Hal ini yang termuat dalam berbagai tulisan Natsir.

Terhadap kelompok orangorang yang cenderung berpihak terhadap kebijakan kolonial ataupun memusuhi Islam, M. Natsir tetap menjaga hubungan baik dalam konteks muammalah, namun tegas ketika sudah meyinggung urusan aqidah dan syari'at. M. Natsir pun menghimbau kepada generasi muda (pada wawancara dalam buku 
"Percakapan Antar Generasi") bahwa kelompok orang yang dikatakan sebagai "abangan" bagaimanapun mereka adalah Islam, dan jangan menjadikannya sebagai musuh atau dituduh sesat atau istilah lain yang menyakitkan.

Mengutamakan persatuan
umat dan menghadapi musuh
bersama (musuh aqidah umat Islam)
merupakan strategi yang dilakukan
oleh M. Natsir. Berbagai lembaga
dakwah Islam yang sudah terbentuk
dinilai oleh Natsir memiliki ciri khas
masing-masing. Mereka berkompeten
dalam gerakan dakwahnya masing-
masing. Inilah yang menjadi modal
potensial umat Islam, yakni
terjadinya polarisasi gerakan untuk
bersama mencapai tujuan. Namun
dalam perjalanannya, potensi ini
belum secara optimal di organisir
dengan baik, dan masih terbuka
lebarnya celah-celah bagi musuh
masuk menyelinap dan memecah
belah antara organisasi Islam
tersebut.

\section{b) Strategi Dakwah bil qalam}

Dakwah Natsir dalam karya tulis jika diamati akan terlihat bermotif deskriptif analisis. Pada kalimat awalnya sebagai pembuka, tulisan M. Natsir (yang terhimpun dalam tiga buku capita selecta, Islam dan Kristen di Indonesia, serta Islam dan Kebudayaan dalam Perspektif Sejarah), menyampaikan maksud dari pesan dalam tulisan, selanjutnya pada paragraf awal ia mendeskripsikan kejadian yang menjadi latar belakang isi tulisan. Pada bagian berikutnya, analisis kritis secara tepat terhadap sasaran disampaikan. Melalui "qaulan-lay-yinan" namun "tajam tikamannya" menjadi rumusannya. Hal tersebut jika ditinjau dalam buku "Fiqh Dakwah" M. Natsir, sesuai dengan cara strategi dakwah yang dipaparkan dalam buku tersebut yakni mengandung pesan untuk memahamkan kita masalah yang perlu diperhatikan dan cara pelaksanaannya dengan "hikmah". Ketegasan dalam pemilihan kata dalam tulisan-tulisan M. Natsir memperlihatkan ketegasan dalam bersikap.

Penumbuhan sikap percaya diri sebagai seorang muslim juga merupakan cara yang tersirat dalam dakwah M. Natsir. Selain itu, penguatan imunitas diri untuk membentuk sebuah karakter yang pantang putus asa disampaikan baik dengan cara lisan ataupun tulisan. Mampu menemukan hal-hal yang perlu dikritisi dan diikuti dengan sikap berani demi meneggakkan kebajikan dan melawan kebatilan, merupakan didikan yang diterimanya dari guru-guru M. Natsir yag telah mendidiknya.

\section{c) Strategi Dakwah bil Lisan}

Dakwah bil Lisan, menjadi salah satu cara yang digunakan oleh M. Natsir untuk menyampaikan Dakwah. Cara ini, meliputi pemberian ceramah/khutbah dalam mimbar-mimbar masjid (seperti penyampaian materi kepada anggota JIB pada masa awal M.Natsir, khutbah jum'at atau khutbah hari Raya, dan acara lainnya), diskusi dengan rekan dakwah atau antar generasi, dan pidato-pidatonya baik yang disampaikan dalam acara-acara kenegaraan ataupun nasional dan Internasional (pidatonya dalam acara 
World of Islam Festival di London dan Pidato Utama pada Sidang ke VIII Muktamar Alam Islamy tanggal 24-28 Maret 1980 di Cyprus). Sebagian besar isi materi penyampaian $M$. Natsir tersebut kemudian dibukukan dalam kapita selecta 2, khuttbah hari raya, Dunia Islam dari masa ke masa dan beberapa sumber lain.

Sama dengan cara menggunakan tulisan, dalam isi materi yang disampaikan memuat unsur penanaman aqidah untuk memperkuat "ketahanan" umat Islam dalam menghadapi berbagai tantangan dan ancaman dari luar yang antara lain berupa Kristenisasi dan nativisasi.

Sementara itu, ceramah lainnya yang disampaikan M. Natsir pada Musyawarah Ummat Islam yang diadakan pada bulan Maret 1976 di Karachi dan Islamabad, Pakistan dengan tema "Apakah Pesan Islam Terhadap Orang Modern?", ia menyampaikan materi pembaharuan dan perubahan dalam Islam yakni tidak menuruti jalan nenek moyang secara membuta seperti yang didasarkan dalam al-Qur'an Qs. AlBaqarah : 170, dan Az-Zuhruf : 22. Disamping itu, pandangan Islam terhadap kemajuan tekhnologi (modernisasi) disampaikan hanyalah suatu cara ke arah tujuan yang lebih tinggi yang disebut dengan al-Ihsan, yakni melakukan perbuatan benar, tanpa mengharapkan suatu imbalan.

Bentuk Implementasi strategi Dakwah Natsir dapat disimpulkan menitikberatkan pada ilmu dan akhlak setelah Tauhid. Kata "Menyadarkan" menjadi sasaran utama kepada umat melalui berbagai bentuk dakwah yang dilakukan. Disadari pembentukan manusia adalah dengan ilmu, yang kemudian dengan aqidah yang baik maka akan melahirkan akhlak yang baik pula. Inilah yang akan membentuk kualitas diri dari setiap muslim. setelah pribadi muslim baik, maka mereka akan menjadi umat yang memiliki imunitas tinggi pula. Sebagaimana yang dipaparkan dalam konsep dakwah Natsir dalam bukunya "Fiqh Dakwah".

\section{Analisis Dinamik}

Analisis dinamik mengantarkan kita kepada melihat langkah dakwah M. Natsir memiliki perkembangan dari waktu ke waktu sesuai dengan kondisi eksternal dan internal masa itu. Diawali dengan ketika ia memulai dakwahnya dari tahap jenjang pendidikan dengan ikut bergabung dalam JIB. Peningkatan wawasan di dunia pendidikan mampu merubah pola pikir seseorang. Pola pendidikan dengan muatan kurikulum yang direncanakan mampu membentuk seseorang sesuai dengan tujuan yang diinginkan. Pendidikan Barat yang menghilangkan unsur agama dalam kurikulumnya akan membawa anak didik menjadi sekular. Pada tahap kelanjutannya mereka akan menjadi kader atau simpatisan penjajah.

Kasus Pancasila dan sejarah serta adat nusantara misalnya, kelanggengan produk nativisasi ini cukup lama dirasa dan tidak disadari oleh banyak orang. Momentummomentum nasional perlu menjadi bahan pertimbangan ulang untuk dievaluasi dengan dilakukan 
perbandingan dengan memasukan kembali fakta sejarah sesungguhnya, maka nilai Islam akan ditemukan menjadi sebuah Identitas yang membentuk Nusantara. Tidak hanya itu, peranan santri dan ulama akan kemerdekaan dirasa menjadi tersingkir dengan dimunculkannya tokoh-tokoh perjuangan yang dikenang dan mendominasi Indonesia adalah tokoh-tokoh Islam namun dekat dengan pemerintahan kolonial dan atau memiliki pemahaman pengembalian agama nusantara kepada agama nenek moyang yaitu animisme dan dinamisme.

Perebutan identitas falsafah Pancasila yang menjadi dasar negara menjadi polemik yang tidak berkesudahan. Hal ini berkaitan dengan Pancasila yang disepakati sebagai ideologi bangsa menjadi sangat erat akan menentukan identitas nusantara itu sendiri. M. Natsir dalam kasus ini cukup tegas mengambil sikap ketika pemaknaan sila-sila Pancasila dihilangkan dari unsur Islam dan dimaknai hal baru yang berupa agama nenek moyang. Ini tercermin dalam sahut- menyahut pidato antara M. Natsir dengan Muhammad Yamin.

Benturan peradaban (Antara Islam dan Kebudayaan tadisional) di Indonesia secara jelas terlihat sejak terjadinya polemik terbuka antara Soekarno dengan A. Hasan dan M. Natsir dalam tataran konseptual. Hal ini terjadi dengan cara mengaitkan Indonesia dengan peradaban Majapahit dan menganggap Majapahit sebagai puncak peradaban tinggi yang kemudian di kuasai Islam dengan menggambarkan Islam sebagai barang asing dan tidak memberikan sumbangan yang berarti bagi Nusantara. Dan Islam di posisikan sebagai musuh tradisi adat. Wujudnya adalah dengan mengembangkan tradisi patung dan monumen dalam kehidupan berbangsa dan bernegara, menciptakan hari nasional dengan tokoh nasional dan berbagai istilah resmi yang kemudian dikaitkan dengan tradisi Jawa dan dijauhkan dari unsur-unsur Islam. (Husaini 2010, 25)

Islam sebagai musuh bagi adat, merupakan pernyataan yang tidak dapat dibenarkan. Islam datang membentuk peradaban yang cerdas, hal ini terbukti dalam sejarah-sejarah Islam yang terukir dalam fakta sejarah. Islam mampu memberikan identitas yang tidak dapat dipisahkan dari adat setempat. Sebagaimana yang terjadi di Jawa, semua orang bumiputera disebut "Wong Selam" (Orang Islam) yang menanadakan adanya akulturasi cukup kuat hingga mencapai akar kebudayaan pribumi itu sediri. Hal ini juga ditunjukkan oleh beberapa serat dan penelitianpenelitian yang sudah dilakukan dengan menampakkan kebenaran bahwa Islam bukanlah musuh bagi adat setempat.

Nativisasi dan sekularisasi (salah satu tantangan dakwah yang juga disebutkan M. Natsir) menjadikan Islam menjadi identitas yang samar. Hingga pada akhirnya, kemunculan berbagai macam namanama Islam (menambahkan satu kata untuk memberi nama jenisnya, sepeti Islam Muhammadiyah, Islam NU, Islam Salafi, dan sebagainya) membuat Persatuan yang terjalin atas dasar Ukhuwah Islamiyah yang 


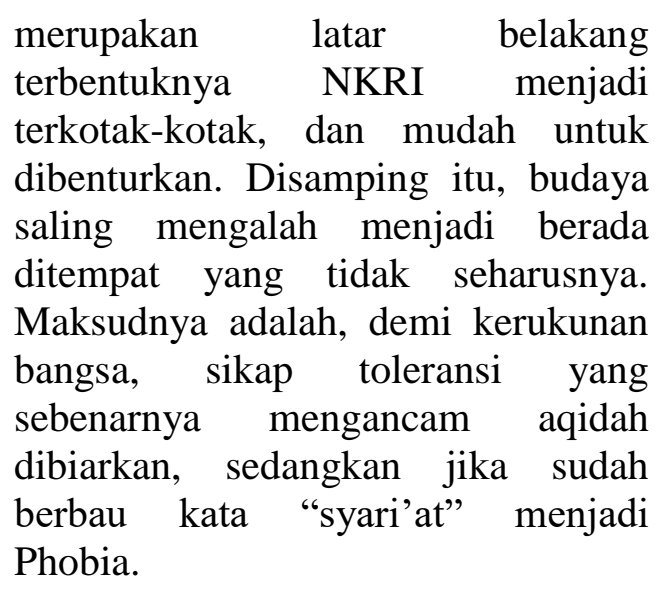

Nativisasi melalui bidang pendidikan dilakukan pula dengan memuat materi-materi sejarah yang menjauhkan peranan Islam dalam Republik Indonesia. (Husaini 2012, 187-202). Sehingga Indonesia yang dikenal sebagai negara mayoritas Muslim terbesar di dunia, dalam mancanegara yang lebih ditinggikan adalah peradaban Hindhu-Budha, candi-candi, dan sejarah peperangan yang menyiratkan bahwa Islam merupakan agama penjajah. Mengenai hal ini, Prof. Hamka pernah menguraikan strategi misionaris Kristen dan orientalis dalam menyerang Islam yang dicatat dalam Tafsir al-Azhar bahwa, melalui sejarah ada upaya pemutusan Nasionalisme dengan Islam.

\section{Implementasi Strategi Dakwah M. Natsir dalam Lembaga DDII}

Strategi dakwah yang terangkum dalam konsep DDII adalah binaan wa difa'an yang merupakan bentuk kegiatan dari amar ma'ruf nahy munkar. Kegiatan pembinaan ini meliputi pendidikan, pengajian, bimbingan, pembinaan rohani, penerbitan buku, pemeberian bantuan, kegiatan sosial, pengobatan, pembangunan sarana dakwah, pemberian materi, pelatihan, peningkatan kualitas ilmu dan wawasan para du'at dan lain sebagainya. Sedangkan kegiatan pembelaan terhadap umat Islam terangkum dalam upaya-upaya mengawal aqidah umat dari adanya faham-faham sempalan termasuk dari aliran-aliran yang mengatas namakan Islam namun memiliki dasar ajaran yang berbeda selain itu, juga upaya pembelaan ini dilakukan untuk merespon misi mionaris yang menggunakan berbagai bentuk strategi pemurtadan.

Prinsip kerja DDII yang menjadi paradigma dakwah organisasi ini berdasarkan Anggaran Dasar Rumah Tangga di rangkum menjadi lima tugas pokok yakni pengawalan aqidah, penegak syari'at, penjalin ukhuwah, pengawal NKRI, dan pendukung solidaritas umat sedunia. Terdapat tiga konsentrasi gerakan utama yang menjadi sasaran dakwah DDII disamping objek lainnya, yakni kelompok-kelompok non-muslim yang ingin memurtadkan orang-orang yang lemah iman di kalangan kaum muslimin (harakatul irtidad), kelompok pemikiran dalam Islam (kelompok SEPILIS) yang lebih dikenal dengan "ghazwul fikr", dan organisasi sempalan yang ingin merusak umat dari dalam (harakah haddamah).

Dakwah $\begin{array}{rr}\text { Program kerja Dewan } \\ \text { baik }\end{array}$ Kristenisasi maupun Nativisasi dapat dianalisis memiliki eksistensi yang sama, hanya Contents (muatannya) saja berbeda, hal ini dipengaruhi oleh kondisi dan situasi lingkungan baik eksternal maupun interal. 
Implementasi dakwah DDII, memiliki landasan tauhid sebagai dasar (tempat bertolak) dalam segala bentuk kegiatannya, dan gerakan dakwah lembaga ini memiliki sasaran dakwah perorangan (melalui pendidikan) kelompok masyarakat, tingkat nasional bahkan internasional (masih menjalin hubungan persaudaraan dengan negara-negara muslim).

\section{Daftar Kepustakaan}

Abdullah, Taufik. 1988. "Ke Arah Perencanaan Strategi Kultural Pembinaan Ummat". dan Penghormatan Generasi Muda. Jakarta : Media Dakwah.

Al- Attas, Syeid Naquib. 2001. Risalah Untuk Kaum Muslimin. Kuala Lumpur : ISTAC.

Anshory, Muhammad Isa. 2013. Mengkristenkan Jawa:Dukungan Pemerintah Kolonial Belanda Terhadap Penetrasi Misi Kristen. Karanganyar : Lir-Ilir.

Bakhtiar, Nurman Agus, murisal. 2005. Ranah Minang Di Tengah Cengkraman Kristenisasi. Jakarta : PT Bumi Aksara.

Banawiratma, J.B. Sepuluh Agenda Pembentukan Persekutuan Jema'at-Jema'at Kontekstual dan Berteologi Kontekstual. Yogyakarta: Kanisius.

\section{F. KESIMPULAN}

Strategi Dakwah M. Natsir meliputi, konsep dakwah dengan berlandaskan pada tauhid, yang dilakukan dengan cara hikmah dan mawwadah fil qurba (memiliki jembatan rasa) yang terimplementasikan dalam bidang pendidikan, karya tulis dan ceramah, struktural serta kultural. Semua ini dilakukan guna mencapai tujuan yakni Baldatun thoyibatun wa Rabbun ghofur.

Basri, Agus . 2008. M. Natsir : Politik Melalui Jalur Dakwah. Jakarta : Media Dakwah.

Basri, Agus . 2008. M. Natsir : Politik Melalui Jalur Dakwah. Jakarta : Media Dakwah.

Hamka. 1982. Pembendaharaan Lama,Cet. 2. Jakarta : Panjimas.

Husaini Adian. 2010. "Indonesia Masa Depan : Perspektif Peradaban Islam". Dalam Membangun Peradaban Dengan Ilmu. Depok : Kalam Indonesia

Husaini Adian. 2012. Pendidikan Islam, Membentuk Manusia Berkarakter dan Beradab. Jakarta : Cakrawala Publishing.

Kaelan, 2012. Metode Penelitian Kualitatif Interdisipliner Bidang Sosial, Budaya, Filsafat, Seni, Agama dan Humaniora. Yogyakarta : Paradigma. 
Khalidy, Mustafa, Omar A. Farrukh. 1953. Missi Kristen Dan Pendjadjahan. Surabaya : Faizan.

Kuntowijoyo. 1994. Paradigma Islam : Interpretasi Unutuk Aksi, cet. $V I$. Bandung : Mizan.

Luth, Thohir. 1999. M. Natsir : Dakwah dan Pemikirannya. Jakarta :Gema Insani.

Mariyanto, Ernest. 2014. Kamus Liturgi Sederhana. Yogyakarta : Kanisius.

Natsir, Mohammad. 1976. World Of Islam Festival dalam Perspektif Sejarah, cet. 2. Jakarta : Yayasan Indayu.

Pratiknya, Atik (peny). 1989. Percakapan Antar Generasi : Pesan Perjuangan Seorang Bapak. Jakarta-Yogyakarta : DDII dan LAPDA.

Puar, Yusuf Abdullah. 1991. Mohammad Natsir 70 Tahun: Kenang-kenangan Kehidupan Perjuangan. Jakarta : Pustaka Antara.

Purwantara, Iswara Rintis. 2012. Prapenginjilan, Menyingkirkan KendalaKendala Intelektual Dalam Penginjilan. Yogyakarta : ANDI.
Purwantara, Iswara Rintis. 2012. Prapenginjilan, Menyingkirkan KendalaKendala Intelektual Dalam Penginjilan. Yogyakarta : ANDI

Shihab, Alwi. 1998. Membendung Arus, Respon Gerakan Muhammadiyah Terhadap Penetrasi Misi Kristen Di Indonesia. Bandung : Mizan.

Suhelmi, Ahmad. 2012. Polemik Negara Islam, Soekarno Vs Natsir, Jakarta : UI-Press.

Susiyanto. 2010. Strategi Misi Kristen memisahkan Islam dan Jawa. Jakarta : Cakra Lintas Media.

Aziz al-Banjari, Rakhmat. 2009. Membaca Ulang Sejarah Walisongo : Respon Atas Nativisasi Islam di Indonesia, dalam Islamia. Volum V, No. 2 : 73.

Susiyanto, 2012. Antara Islam dan Kebudayaan Candi, dalam Islamia. Vol II No. 2.

http://sp2010.bps.go.id/

Husaini, Adian. 2009. Tiga Tantangan Dakwah Umat Islam. (Online), (http://www.gaulislam.com /. Diakses 6 Januari 2015). 